\title{
Konya'da Faaliyet Gösteren 5 Yıldızlı Otel Yöneticilerinin Gelir Yönetimine Bakışları (Overviews of 5 Starred Hotels' Managers Which Operate in Konya on Revenue Management)
}

\section{Semih BÜYÜKİPEKCI iD a İslam İSLAMZADE iD a}

a Selçuk Üniversitesi, Turizm Fakültesi, Turizm İşletmeciliği Bölümü, Konya, Türkiye. sbipekci@selcuk.edu.tr

a Selçuk Üniversitesi, Sosyal Bilimler Entitüsü, Turizm İşletmeciliği Bölümü, Konya, Türkiye. islamislamzade1996@gmail.com

\begin{tabular}{ll}
\hline MAKALE BíLGİSI & ÖZET \\
\hline Anahtar Kelimeler: & Amaç - Bu çalışmanın temel amacı, Konya'da faaliyet gösteren 5 yıldızlı otel işletmelerinde gelir \\
Otel İşletmeleri & yönetimi uygulama şekilleri ve uygulama durumu belirlenerek, işletmelerde yönetici pozisyonunda \\
Gelir Yönetimi & yer alan çalışanların gelir yönetimi uygulamalarına bakış açıları, müşteri profiline göre ve işletmede \\
Otel İşletmelerinde Gelir & gelir yönetimi departmanının bulunup bulunmamasına göre gösterebileceği değişiklikler \\
Yönetimi & incelenmiştir.
\end{tabular}
Yönetimi

Yöntem - Örneklem olarak Konya ilinde faaliyet gösteren 5 yıldızlı otel işletmelerinden 2020 yılı içerisinde görev alan üst düzey yöneticiler seçilmiş ve olasılığa dayalı olmayan örnekleme yöntemlerinden amaca göre örnekleme yöntemi tercih edilerek katılımcılara anket çalışması yapılmıştır. Anket çalışması sonucunda elde edilen verilere uygun paket programlarından

Gönderilme Tarihi 10 Ağustos 2020

Revizyon Tarihi 23 Ocak 2021

Kabul Tarihi 5 Mart 2021

Makale Kategorisi:

Araştırma Makalesi faydalanılarak güvenirlilik ve geçerlilik (faktör analizi), standart sapma, aritmetik ortalama, frekans, yüzde dağılımı, normallik (Kolmogorov-Smirnov) ve farklılık (T- testi ve Anova) testleri uygulanmıştır.

Bulgular - Analizler sonucunda araştırmanın yapıldığı otellerde gelir yönetimi uygulamaları son yıllarda daha çok kullanılmakta olduğu ve gelir yönetimi uygulamalarını kullanan işletmelerin çoğunda gelir yönetimi müdürünün bulunduğu görülmektedir. Aynı zamanda aylık gelir, müşteri profili, gelir müdürünün bulunması ve gelir yönetimi komitesinin kurulup kurulmaması gibi seçilmiş çeşitli gruplarla gelir yönetiminin değerlendirilmesi arasında yapılan farklılık testlerinin anlamlı olmadığı sonucuna ulaşılmıştır.

Tartışma - Bu konuyla ilgili literatür taraması yapıldığında gelir yönetimi uygulamaları üzerinde farklılık yaratabilecek faktörler olarak daha çok demografik özellikler ve işletme faaliyet süresi gibi etkenlerin dikkate alındığı görülmektedir. Bu araştırmada ise gelir yönetimi uygulamaları üzerinde farklı sonuçlar yaratabilecek etkenler olarak; aylık gelir, müşteri profili, gelir müdürünün bulunması ve gelir yönetiminin bulunma zorunluluğu gibi faktörler söz konusu istatistik analizlere tabi tutulmuştur. Yapılan analizler sonucunda herhangi bir anlamlı farklılığa ulaşılmamasına rağmen, araştırma hem alana sağladığı farklı bakış açısı yönünden hem de özgün literatür açısından ileride yapılacak araştırmalar için referans özelliği taşımaktadır.

\section{ARTICLE INFO}

\section{ABSTRACT}

\section{Keywords:}

Revenue Management

Hotel Enterprises

Revenue Management in Hotel Enterprises.

Purpose - The main purposes of this work are to determine the income management methods and application status in 5 star hotel enterprises operating in Konya, and the perspectives of employees in managerial positions in the enterprises; Changes that may show according to the customer profile and the presence or absence of the revenue management department in the business were examined.

Design/methodology/approach - As the sample, senior executives from the 5-star hotel businesses operating in Konya were selected in 2020, and a questionnaire study was conducted with the participants by choosing the sampling method according to the purpose, one of the nonprobability-based sampling methods. The data obtained as a result of the survey study were analyzed statistically and interpreted in the form of tables. Reliability and validity (factor analysis), standard deviation, arithmetic mean, frequency, percentage distribution, normality (Kolmogorov-Smirnov) and difference (T-test and Anova) tests were performed by using the package programs suitable for the data obtained from the survey study.

Findings - As a result of the analyzes, it is seen that revenue management applications have been used more in recent years and it is also seen that most of the enterprises using revenue management practices have revenue management manager. At the same time, it was concluded

\section{Önerilen Atıf/ Suggested Citation}

Büyükipekci, S., İslamzade, İ. (2021). Konya'da Faaliyet Gösteren 5 Yıldızlı Otel Yöneticilerinin Gelir Yönetimine Bakışları, İşletme Araştırmaları Dergisi, 13 (1), 176-191. 
that the difference tests performed between the various groups selected such as monthly income,

Article Classification:

Research Article customer profile, presence of the revenue manager and the establishment of the revenue management committee and the evaluation of the revenue management are not significant.

Discussion - It is observed that factors such as demographic characteristics and company activity life are taken into consideration as factors that may make a difference in revenue management applications while searching the literature on this subject. In this research, as factors that may have different results on revenue management applications; Factors such as monthly income, customer profile, presence of revenue manager and obligation of revenue management were subjected to these statistical analyzes. Although no significant difference has been reached as a result of the analysis, the research can be a reference for future studies both in terms of its different point of view and its original literature.

\section{GíRiş}

Gelir Yönetimi kavramı 1978 yılında Amerika'da uçuş fiyatlarının serbest bırakılmasından sonra ortaya çıkmıştır. Bu sistem zaman içerisinde bazı araç kiralama firmaları tarafından kullanılmış ve 1980 li yılların ortalarında Marriot, Hyatt gibi zincir oteller tarafından kullanılmaya başlanmıştır. Küreselleşen dünyada gelişmiş ülkelerde teknoloji ve güç hızlı bir şekilde el değiştirmektedir. Her gün yeni otel işletmeleri hizmete açılmaktadır. Açılan bu büyük tesisleri doldurmak için işletmecilerin doğru stratejiler izlemesi ve sektörle ilgili yenilik ve trendleri yakından takip etmesi zorunluluğu ortaya çıkmıştır. Araştırma konusunun 5 yıldızlı otel işletmelerinde gelir yönetimi uygulamaları seçilmesinin ana sebebi, gelir yönetimi uygulamalarının otelin karına, sürdürülebilirliliğine ve gelişimine vermiş olduğu önemi öne çıkarmaktır. Ayrıca otel işletmeleri hızlı gelişme gösteren bir ortamda bulundukları için bu ortama uyum sağlamalarında gelir yönetimi sistemine ne derecede önem verdiklerini ortaya koymaktır. Bunun yanı sıra araştırma sonuçlarının işletmelerle paylaşılması ve onlara öneriler sunulması işletmelere faydalı olması amaçlanmaktadır. Günümüzde gelir yönetiminin ülkemizdeki kullanımına baktığımızda, bu çalışmanın gelecekte otel işletmelerinin gelir yönetimi uygulamalarını daha etkin kullanmasına katkı sağlayacağı düşünülmektedir. Aynı zamanda bu araştırma gelir yönetimi uygulamaları ile ilgili yapılacak olan çalışmalara örnek olması amaçlanmaktadır.

Gelir yönetimi havacılık endüstrisinde hem teorik bir çerçeve hem de bir ticari uygulama olarak çok iyi geliştirilmiş olsa da, turizm alanında yeterince ilgi görmemiştir. Bu bağlamda, araştırmanın temel amacı, Konya'da faaliyet gösteren 5 yıldızlı otel işletmelerinde gelir yönetiminin uygulama şekillerinin, uygulama durumunun belirlenmesidir. Ayrıca işletmelerde kullanılan gelir yönetimi uygulamalarının aylık gelir, gelir yönetimi müdürünün bulunup bulunması, gelir yönetimi için komitenin kurulup kurulmaması, otelin müşteri profili gibi çeşitli guruplara göre gösterebileceği farklılıklar alt amaç olarak incelenmektedir.

Yapılmış çalışmanın literatür bölümünde bu konuyla ilgili önceden yazarların yapmış oldukları çalışmalar ve araştırma sonunda vardıkları sonuçlardan bahsedilmektedir. Çalışmada kuramsal çerçeve bölümünde gelir yönetimi ile ilgili genel bilgiler, gelişimi, tarihi ve turizm işletmelerinde gelir yönetimi uygulamaları ile ilgili bilgilere yer verilmiştir. Çalışmanın yöntem bölümünde ise araştırmanın evren ve örneklemi, veri toplanması, araştırmanın yöntemi, güvenirlilik ve geçerlilik testinin sonucu belirtilmiştir. Çalışmada yapılan analizler ve testler tablolar şeklinde yorumlanarak bulgular kısmında gösterilmiştir.

Bu konuyla ilgili literatür taraması yapılırken gelir yönetimi uygulamaları üzerinde farklılık yaratabilecek faktörler olarak daha çok demografik özellikler ve işletme faaliyet süresi gibi etkenlerin dikkate alındığı görülmektedir. $\mathrm{Bu}$ araştırmada ise gelir yönetimi uygulamaları üzerinde farklı sonuçlar doğurabilecek etkenler olarak; aylık gelir, müşteri profili, gelir müdürünün bulunması ve gelir yönetiminin bulunma zorunluluğu gibi faktörler söz konusu istatistik analizlere tabi tutulmuştur. Yapılan analizler sonucunda herhangi bir anlamlı farklılığa ulaşılamamasına rağmen, araştırma hem alana sağladığı farklı bakış açısı yönünden hem de özgün literatürü açısından ilerideki çalışmalara referans olabilecek niteliktedir.

\section{LITERATÜR}

Kimes ve Thompson (2004) “Chevys'de Restoran Gelir Yönetimi: En İyi Masa Karışımını Belirleme” isimli çalışmasında, orta ölçekli bir restoran işletmesinin tedarik karışımının iyileştirilmesi geliri yılda\% 5,1 artırdığının sonucuna ulaşmışlardır.

Choi ve Mattila (2004) “Otel gelir yönetimi ve müşterilerin adalet algılarına etkisi” konusunu araştırmışlardır. $\mathrm{Bu}$ araştırmada yazarlar, gelir yönetimi uygulamalarının müşterilerin adalet algıları üzerindeki etkisini 


\section{S. Büyükipekci - İ. İslamzade 13/1 (2021) 176-191}

ampirik olarak test etmişlerdir. Ayrıca, rezervasyon sırasında müşterilere verilen oda fiyatlandırma uygulamaları hakkındaki bilgilerin etkisi araştırılmıştır. Otel gelir yönetimi uygulamalarının adaletsizlik algısına yol açabileceği sonucuna varılmıştır. Adalet hakkındaki bu endişenin düzeyi, otel müşterilerinin başkalarının oda fiyatlarını öğrenmesinin ne kadar kolay veya ne kadar yaygın olduğunun sonucuna varılmıştır. Ancak otel gelir yönetimi uygulayıcıları için bu çalışmadan elde edilen sonucun pozitif yönü, rezervasyon anında müşterilere otel gelir yönetimi uygulamaları hakkında bilgi vererek adaletsizlik sorununu çözebilecekleridir.

Kimes (2004) "Restaurant Revenue Management" adlı çalışmasında Chevys Arrowhead de gelir yönetimi taktiklerini uygulayarak geliri yaklaşık yüzde \%5 artırmayı başarmıştır. İyileştirilmiş sofra karışımı, hizmet sunumundaki değişiklikler ve iyileştirilmiş eğitim restoran performansının yükselişine yol açmıştır. Koltuk kullanımı ve RevPASH artması, yemek süresi ve çeşitliliğinin azaltması gelirin artmasına neden olmuştur. Diğer restoran işletmecileri de mevcut performanslarını dikkatli analiz ederek, bu performansın nedenlerini belirleyerek performansını geliştirmek için uygun stratejiler geliştirerek benzer sonuçlar elde edebileceği sonucuna varılmıştır.

Gür (2014) tarafından yapılan "Gelir Yönetimi Uygulamaları: Ankara'daki Otel İşletmeleri Üzerinde Araştırma" başlıklı tez çalışmasında işletme belgeli dört yıldızlı otel işletmelerinde gelir yönetimi sistemine ilişkin algılarının henüz iyi bir seviyede olmadığına, gelir yönetimini kullanan otelin karlılığının ve doluluk oranının arttığına, araştırmaya katılan otel işletmelerinin çoğunda gelir yönetimi komitesinin kurulmadığı sonucuna ulaşmıştır.

Korkmaz (2014) tarafından yapılan “Küçük Ve Orta Ölçekli Konaklama İşletmelerinin Odalar Bölümünde Gelir Yönetimi" başlıklı çalışmanın sonuçlarına göre, tesislerin gelir yönetimine hazırlık aşamasında bulunan işletmelerin alt faaliyetleri yerine getirmede farklılık göstermedikleri, yani genelde tesislerin yetkili birim belirleme, en az iki yıllık veri bankası oluşturma gelir yönetimi stratejisi ile otel stratejisini uyumlaştırma, personel için performans ölçme siteminin belirlenmesi faaliyetlerinde düşük, orta ve yüksek düzeyin birbirlerinden farklı uygulamalarda bulunmadığı görülmüştür. Ancak gelir yönetimi konularında personele eğitim verilmesi ve genel olarak hazırlık toplam puanına bakıldığında, düşük, orta ve yüksek düzeyin hazırlık aşamaları uygulamalarının farlılıklar gösterdiği sonucuna ulaşılmıştır. Yapılan araştırma sonuçlarına genel olarak bakıldığında; KOBİ’lerin gelir yönetimi uygulamaları düzeylerinin genellikle orta düzey olduğu anlaşılmıştır.

\section{KURAMSAL ÇERÇEVE}

Gelir yönetiminin ortaya çıkışı, 1970“lerin sonunda ABD hava yolu sektöründe gerçekleşmiş serbestleşme hareketine dayanmaktadır. Müşterilerine minimum hizmetleri düşük fiyatla satmak için Peoples Express adiyla yeni bir havayolu şirketi kurulmuştur. Peoples Express ile rekabet etmeye karar veren United ve Amerikan gibi büyük taşıyıcı firmalar, az sayıda koltuğu daha düşük fiyata, diğer kalan koltukları ise yüksek fiyatlarla pazara sunmaya başlamışlardır. Bununla birlikte hem Peoples Expressin müşterilerini hem de diğer yüksek fiyat ödeyen müşterileri taşımayı başarmışlardır. Sonuçta Peoples Expressin müşterileri büyük taşıyıcı firmaları tercih ederler. Peoples Express bir süre sonra iflas ettiğini ilan etmiştir. Peoples Expressin eski başkanlarından biri olan Donald Burr, şirketin iflas etmesinin sebeplerinden biri olarak gelir yönetimi sisteminin olmadığını söylemiştir. Ülkemizde gelir yönetiminin tanıtılması, 90'lı yılların başlarında Türk Hava Yolları'nın dış hat uçuşlarında gelir yönetiminin kullanılmasıyla başlanmıştır. Türk Hava Yolları 1997 yılında liderlik yaparak bilgisayarlı gelir yönetimi sistemine geçmiştir. Ülkemizde otelcilik sektöründe yabancı zincir oteller tarafından başlatılan gelir yönetimi uygulamalarının günümüzde yaygın olarak kullanıldığı görülmektedir (Kurgun, 2008).

Gelir yönetimi, son yıllarda gelirlerini artırmak için istikrarlı kapasitesi ve esnek talebi olan şirketlerin kullandığı yöntemlerden birisidir. Kimes'e (1989) göre gelir yönetimi, doğru hizmetin doğru müşteriye doğru zamanda ve doğru fiyatla satılmasını sağlayan bir yöntem olarak tanımlanmaktadır. Genel olarak gelir yönetimi yöntemleri, fiyat farklılıkları ve kapasite yönetimi olarak birleştirilmeden tanımlanabilir (Belobaba, 1987). Gelir yönetiminin amacı, talebi karşılamak için en uygun kapasiteyi ve en uygun fiyat politikasını belirlemektir. Gelir yönetimi talep ve piyasa sınıflandırmasına dayanmaktadır. Tüm pazarlarda fiyat üzerinde farklı hareket eden gruplar vardır ve bu gruplar belirli fiyatlara farklı tepki verirler. Bu nedenle, fiyat 
ayrımcılığı gelir yönetiminin kilit unsurlarından biridir. Fiyat, bu reaksiyonlara bağlı olarak değişir. Bu, gelir yönetimi Altunışık vd. (2010) belirlemek ve geliri artırmak için yapılmaktadır.

Son yıllarda işletmeler, satış ve kârlılığı arttırmada gelir yönetiminin yeterliliklerinin farkına varmaktadır. Ancak akademik çerçevede gelir yönetimini anlamak ve tanımlamak zordur. Cho ve Choi'ye (2000) göre gelir yönetimi farklı tanımlamalar yapılmakla birlikte araştırılan alana göre ortak bazı kavramlarla da açıklanabilmektedir. Özel olarak da fiyatlandırma ve gelir yönetimi, fiyatlandırma ve gelir optimizasyonu, gelir süreci optimizasyonu, talebin yönetimi, bozulabilir-stoklanamaz varlıkların gelir yönetimi eş anlamlı olarak kabul edilmektedir (Jerenz, 2008).

Gelir yönetimi kavramı yurtiçi çalışmalarda gelir yönetimi, hâsılat yönetimi gibi kavramlarla ifade edilirken, İngilizce literatürde "Revenue Management" veya "Yield Management" olarak ifade edilmektedir (Sığırcı, 2015). Havayolu işletmelerinde ilk olarak ortaya çıkan bu kavram uygun zamanda uygun müşteriye uygun koltukların satılmasıyla gelirlerin üst düzeye çıkarılması olarak tanımlanmıştır. Benzer bir biçimde Amerikan havayolları ilk olarak gelir yönetiminin amacını müşteri gelirlerini maksimize etmede doğru koltukları, doğru müşterilere doğru zamanda satmak olarak tanımlamışlardır (Yu, 1998).

Havayolu işletmeleri ve otel işletmelerinin yapısı gereği sabit kapasiteye sahip olmaları, diğer bir ifadeyle inşa edilen bir otelin oda sayısını arttırabilmenin çok maliyetli ve uzun zaman gerektirmesi, bir uçağın koltuklarının arttırılamayacak olması nedeniyle, kısıtlı kaynakları yüksek kârlılıkla kullanabilmek gelir yönetiminin önemini açılamaktadır. Donaghy (1997) gelir yönetiminin, otelin finansal performansını arttırmada önemli bir potansiyele sahip olduğunu belirtmektedir. Bazı çalışmalar gelir yönetiminin, gelirlerin arttırılmasının aksine kârlılığın arttırılması gerektiğini vurgulayan bir yönetimsel araç olduğunu benimsemektedir (Zheng Gu, 1998). Gelir yönetimi uygulamalarının, müşteriler tarafından algılanan kalite ile müşteri memnuniyetini etkilemesi firma performansı ile olumlu ilişki içerisinde olması, işletmeler için en önemli konulardan birisi olan firma performansını etkilemesi konunun önemini açıklamaktadır (Capiez \& Kaya, 2004).

Departmanlar arasında koordineli bir biçimde yürütülmesi ve kararlar alınması gereken etkili bir gelir yönetiminde sayısal analizler ve pazarlama tekniklerinden yararlanılmakla birlikte kapasite yönetimi de önem taşımaktadır. Bu bağlamda Annaraud (2008) otel işletmelerinde gelir yönetiminin önemini, oda fiyatlandırmasının her otel için rekabet ve yüksek kâr elde edebilmeleri için önemli konu olduğunu belirtmektedir.

Otel işletmelerinde gelir yönetimi, oda ve oda bağlantılı hizmetlerin satısından fiyat, talep ve kapasite denetimi ile en yüksek geliri elde etmeyi amaçlamaktadır. Gelir yönetimi, kısa vadede gelirin artırılmasına uzun vadede ise karın artırılmasına yönelik sistematik bir yaklaşım sunmaktadır. Gelir yönetimi, konuğun tüketim eğilimi ile ilgili bilgileri kullanarak hizmet satışında fiyat ve kapasite denetimini sağlamaktadır. Otel işletmelerinde gelir yönetiminin amaçları aşağıdaki gibi sıralanabilir:

> Fiyatların en etkin bir biçimde yapılandırılması,

> Talebin düştüğü zamanlarda doluluğun artırılması, talebin yükseldiği zamanlarda da gelirin artırılması,

$>$ İndirimli fiyatların denetiminin sağlanması,

$>$ Toplam talep ve fiyat esnekliğini göz önünde bulundurarak gelir ve pazar kaybının en düşük düzeye indirilmesi,

> İndirimli fiyatlarla satın alma yapan pazar bölümlerinin yüksek fiyatlarla satın alma yapan pazar bölümlerinin yerini kullanmasının engellenmesi,

$>$ Mevcut ve potansiyel pazardan en yüksek gelirin elde edilmesi (Ören, 2005).

\subsection{Turizm İşletmelerinde Gelir Yönetimi}

Havayolu işletmelerinde başlayan ve daha sonra benzer özellikli birçok sektör tarafından uyarlanan gelir yönetiminin en çok benzerlik gösterdiği işletmelerin otel işletmeleri olduğu söylenebilir. Bu özelliklerde her iki sektörde de ileri tarihli rezervasyon imkânı vardır (Lai, 2005).

Çeşitli sektörlerde gelir yönetimi kullanımına yönelik bilgiler Tablo 1'de sunulmuştur (Guadıx, 2011). Otel başlığı altında fiyat farklılaştırması, bölümlendirme ve dağıtım kanalları ile sözleşmelere ilişkin açıklama yer almaktadır. Araç kiralama ve demir yollarında da talep dalgalanmasına yönelik örnekler verilmiştir. Son 


\section{S. Büyükipekci - İ. İslamzade 13/1 (2021) 176-191}

olarak restoran işletmelerinde de talebin yoğun ve az olduğu benzer biçimde talep dalgalanmasında uygulanan tekniklerden birkaç örnek verilmiştir.

Tablo 1. Çeşitli Sektörlerde Gelir Yönetimi Kullanımı

\begin{tabular}{|l|l|}
\hline Sektör & \multicolumn{1}{|c|}{ Hizmet } \\
\hline Havayolları & $\begin{array}{l}\text { Çeşitli kategorilerde bilet satışı yapılmaktadır. (Ekonomi, iş dünyası gibi) Uçuş } \\
\text { öncesi fiyat değişikleri yapılabilmektedir. }\end{array}$ \\
\hline Otel & $\begin{array}{l}\text { Farklı müşterilere farklı fiyatlardan satışlar yapılabilmektedir. Dağıtım } \\
\text { kanallarında farklı fiyatlardan oda satışları yapılabilmektedir. }\end{array}$ \\
\hline Araç Kiralama & $\begin{array}{l}\text { Talebin düşük olduğu yerlerde ve zamanlarda çeşitli anlaşmalar } \\
\text { yapılabilmektedir. Araç uygunluğuna göre değişen fiyatlarla araçlar kiraya } \\
\text { verilebilmektedir. }\end{array}$ \\
\hline Demiryolları & $\begin{array}{l}\text { Müşteriler haftanın farklı günlerinde ve günün farklı zamanlarına göre fiyat } \\
\text { değişikliklerini ödeyebilecek gruplara ayrılır. }\end{array}$ \\
\hline Restoranlar & $\begin{array}{l}\text { İlerin yavaş olduğu zamanlarda restoranlar indirim kuponları ve özel menüler } \\
\text { sunmaktadırlar. Yoğun saatlerde fiyatlar yükselebilir. }\end{array}$ \\
\hline
\end{tabular}

(Guad1x, 2011).

Otel İşletmelerinde Gelir Yönetimi - Yaygın olarak havayolu işletmeleri, otel işletmeleri ve araç kiralama sektörlerinde kullanılan gelir yönetimi, işletmenin gelirlerini en yüksek düzeye getirebilmek için uygulanan bir yöntemdir (Bertsimas \& Shioda , 2003). Gelir yönetimi, uygun zamanda uygun fiyattan uygun müşteriye kalan uygun kapasitenin satılmasıyla ilişkilidir. Pazar, bölümlendirme, zamanlama (arz ve talebin zamanında yönetimi) ve fiyatlandırma gelir yönetiminin en önemli üç özelliğidir. Bütün bu özelliklerin başarılı bir şekilde uygulanması, uygulayan firmalara başarı getirebilecektir (Sanchez, 2005; Padhi, 2011). Gelir yönetimi otel işletmelerinin rekabetçi duruşlarını geliştirirken genel kârılığı da arttırmaktadır. Gelir yönetimini, gelirin maksimuma ulaşmasında odaların fiyatlandırılmasını ve kontrolünü içeren genel ekonomik ilkelerin uygulanmasıdır (Relihan, 1989). Otel işletmelerinde gelir yönetimi, uygun yatak kapasitesine göre önceden belirlenmiş pazar bölümlerinde en iyi fiyatı belirlemek amacıyla uygulanan bir gelir maksimizasyon tekniğidir. Otel işletmeleri yöneticileri, otelin kapasite miktarında sahip olduğu otel odalarını özellikle yüksek talebin meydana geldiği dönemlerde en yüksek kârı elde edebilecek biçimde satabilmek amacıyla çeşitli fiyatlandırma teknikleri uygulamışlardır. Uygulanan bu tekniklerden birisi de gelir yönetimidir (Cho \& Choi, 2000).

Yiyecek İçecek İşletmelerinde Gelir Yönetimi - Yiyecek içecek işletmeleri kapsamında özellikle restoran işletmelerinde gelir yönetimi ile ilgili çalışmaların (Bertsimas \& Shioda , 2003) özellikle son yıllarda arttığı görülmektedir. Tablo 2' de işletmeler için ürün grubu ya da iş birimi analizi için yapılan müşteri kârlılık matrisi görülmektedir. Söz konusu matriste VIP grubu yüksek harcama ve yüksek devamlı müşteri frekansına sahip olduğu görülmektedir. Müdavim grubu da benzer bir biçimde yüksek devamlı müşteri frekansı grubunda yer alırken harcamalar düşüktür. Özel grubunun yüksek harcama, düşük devamlı müşteri frekansında yer aldığı görülmektedir. Kitle grubu ise, düşük devamlı müşteri frekansı ve düşük harcama grubunda yer almaktadır. Söz konusu bu gruplandırma yardımıyla yöneticiler ürün gruplarının ve iş süreçlerinin yapılandırmasında belirli gruplar üzerinde yoğunlaşarak gelirlerin arttırılmasında bu gruplara özel teknik ve stratejiler gerçekleştirmektedirler (Bujisic, 2014).

Tablo 2. Müşteri Kârlılık Matrisi

\begin{tabular}{|c|c|c|}
\hline Yüksek Harcama & Özel & VIP \\
\hline Düşük Harcama & Kitle & Müdavim \\
\hline & $\begin{array}{c}\text { Düşük devamlı müşteri } \\
\text { frekansı }\end{array}$ & Yüksek devamlı müşteri frekansı \\
\hline
\end{tabular}

(Bujisic, 2014).

Kimes (2003) restoran işletmelerinde talebin yoğun yaşandığı zamanlarda yemek süresini kısaltmanın gelirleri arttırdığını belirtmişlerdir. Bujisic (2014) ise bir örnekle içecek işletmelerinde salı günleri gibi talebin çok az 
olduğu zamanlarda "Öğrenci Geceleri” adı altında indirimli etkinlikler yaparak işletmenin satış ve gelirlerini arttırabileceğini söylemiştir.

Seyahat Acentalarında Gelir Yönetimi - Turların fiyatlandırılmasında ulaşım, konaklama, yemekler, müze ören yerleri giriş ücretleri ve rehberlik hizmetleri, zorunlu sigorta hizmetleri ile birlikte diğer bir takım giderler de eklenerek seyahat acentalarının belirlenen maliyet fiyatının üzerine kâr marjının ilave edilmesi ile müşteriden talep edilecek fiyat ortaya çıkacaktır. Bu fiyat paket tur fiyatı olarak adlandırılmaktadır. Bu paket turların pazarlanmasında ise genel olarak broşür yaratma, reklamcılık, halkla ilişkiler ve bireysel satış tekniklerinden yararlanılmaktadır (Öz, 2015). Seyahat işletmelerinin de diğer turizm sektörü ile ilgili olduğu ve benzer özellikleri taşımasından dolayı gelir yönetimi ile ilgili çalışmaların bu alanda da arttığı gözlenmektedir.

\section{YÖNTEM}

$\mathrm{Bu}$ araştırmanın temel amacı, Konya"da faaliyet gösteren 5 yıldızlı otel işletmelerinde gelir yönetiminin uygulama şekillerinin, uygulama durumunun belirlenmesidir. Ayrıca işletmelerde kullanılan gelir yönetimi uygulamalarının aylık gelir, gelir yönetimi müdürünün bulunup bulunmaması, gelir yönetimi komitesinin kurulup kurulmaması, otelin müşteri profili gibi çeşitli guruplara göre gösterebileceği farklılıklar alt amaç olarak incelenmektedir. Yapılan bu çalışmada ayrıca işletmelerin gelir yönetimini kullanma durumları, kullanma süreleri ve gelir yönetimi departmanının bulunmadığı işletmelerde gelir yönetiminin görev ve sorumluluklarını yerine getiren yöneticilerin veya gelir yönetimi komitesinin olup olmadığının belirlenmesi araştırılmaktadır. Otel işletmeleri hızla gelişen bir ortamda bulunduğundan, bu ortama adapte olurken kullandıkları gelir yönetimi uygulamalarının otelin gelişimine ne kadar katkı sağladığı önem taşımaktadır. Ayrıca, işletme için araştırma sonuçlarını paylaşmak ve onlara önerilerde bulunmak önemlidir. Araştırmanın evreni Konya ilinde faaliyet gösteren 5 yıldızlı otel işletmeleri ile sınırlanmaktadır.

\subsection{Araştırmanın Evreni ve Örneklemi}

Araştırma evreni Konya ilinde faaliyet gösteren beş (5) yıldızlı otel işletmelerinde çalışan üst düzey yöneticilerden oluşmaktadır. Beş yıldızlı otel işletmelerinin evren olarak seçilmesinin nedeni, bu otel işletmelerinin diğer konaklama işletmelerine göre tam kurumsallaşması ve çağdaş gelir yönetimi uygulamalarını kullanmasıdır. Konya İl Kültür ve Turizm Bakanlığı'nın 2020 yılında paylaştığı verilerde Konya İlinde 7 tane 5 yıldızlı otel faaliyet göstermektedir.

Evrenin \%10'nu betimsel araştırmalarda örneklem için olabilecek en az oran olarak dikkate alınır. Budan daha küçük evrenler için \%20 gerekebilir (Yener \& Gül, 2007). Fox'a (1969) göre bazı durumlarda tek bir birimin bile evreni temsil edebilir. Temsili olan (20) kişilik bir örneklem, temsili olmayan (400) kişilik örneklemden daha iyidir. Araştırmanın gelirler ile ilgili olduğu göz önünde bulundurulduğunda tekniklerin uygulanma, önem ve işletmeye sağladığı katkıyı açılayabilecek temsil grubunun yöneticiler olduğu ve bu doğrultuda ulaşılmış yöneticilerin evreni temsil edebileceği düşünülmektedir. Araştırma evren sayısının bilindiği durumlarda, örneklem büyüklüğü belirlemek için (Salant \& Dillman, 1994) tarafından hazırlanan formülden yararlanılmaktadır:

$$
\frac{N \cdot t^{2} \cdot p \cdot q}{(N-1) \cdot d^{2}+t^{2} \cdot p \cdot q}
$$

Formülde,

$\mathrm{N}=$ Evrendeki birey sayıs

$\mathrm{N}=$ Örnekleme alınacak birey sayısı

$\mathrm{T}=$ Belirli bir anlamlılık düzeyinde, T-Tablo'suna göre bulunan teorik değer

$\mathrm{d}=$ Olayın görülüş sıklı̆̆ına göre yapılmak istenen + sapma olarak simgelenmiştir.

$\mathrm{P}=$ İncelenecek olayın görülüş sıklığı (gerçekleşme olasılığı)

$\mathrm{Q}=$ İncelenecek olayın görülmeyiş sıklığ 1 (gerçekleşmeme olasılığı)

$$
\frac{60 \cdot 1,96^{2} \cdot 0,8 \cdot 0,2}{(60-1) \cdot 0,05^{2}+1,96^{2} \cdot 0,8 \cdot 0,2}=48,38
$$


Bu bağlamda, \% 95 güven aralığında ve \% 5 hata payı ile örneklem kütle sayısı 48 olarak hesaplanmıştır. Veri toplama sürecinde 5 otelden 50 katılımcının cevapladığı değerlendirmeye uygun anket elde edilmiştir. Örneklem araştırma evrenini temsil edecek niteliktedir. Araştırmada veri toplama aracı olarak anket kullanılmıştır. Araştırmada örneklemi alınacak yöneticilerin oluşturulmasında olasılığa dayalı olmayan örnekleme yöntemlerinden amaca göre örnekleme yöntemi tercih edilmiştir. Zaman, maliyet zorluğu ve COVID-19 pandemisinden dolayı evrendeki 60'a yakın üst düzey yöneticinin tamamına ulaşılamamıştır.

\subsection{Araştırmanın Yöntemi ve Veri Toplama Aracı}

Araştırmanın yöntemi nicel araştırma yöntemidir. Verilerin toplaması için yüz yüze anket tekniği kullanılmıştır.. Araştırmada uygulanmakta olan anket soruları iki bölümden oluşmaktadır. Birinci bölümde, anketi cevaplayan yöneticilerin sosyo-demografik özellikleri ve çalıştıkları otel işletmelerinin belli başlı nitelikleri hakkında bilgi edinilmeye çalışılmıştır. İkinci bölümde ise gelir yönetimi uygulamaları ile ilgili öneriler cevaplanmıştır. Yöneticilerin, bu değişkenleri 5'li Likert ölçeğine göre yanıtlamaları istenmiştir (1: Kesinlikle Katılıyorum, 2: Katılıyorum, 3: Kararsızım, 4: Katılmıyorum, 5: Kesinlikle Katılmıyorum). Toplam 30 önerme sorulmuş ve anketin oluşturulmasında Unurlu (2010), tarafından kullanılan ölçeklerden yararlanılmıştır. Anket çalışması 10 Şubat 2020- 17 Şubat 2020 tarihleri arasında yöneticilerle bire bir görüşme yoluyla gerçekleştirilmiştir. Anketler, otel işletmelerinin otel sahibi, genel müdür, ön büro müdürü gibi işletmeyi iyi tanıyan yöneticiler tarafından cevaplandırılmıştır. Toplanan veriler uygun paket programı ile analiz edilmiştir.

\subsection{Verilerin Analizi}

Araştırmada elde edilen veriler uygun paket programı ile çeşitli analizlere tabi tutulmuştur. Güvenirlilik ve geçerlilik ( faktör analizi) testleri ile anket içindeki soruların ne kadar kararlı, tutarlı ve duyarlı olduğu ölçülmüştür. Verileri topladıktan sonra değişkenlerin betimsel istatistiği yapılmıştır. Toplanmış verilerin standart sapma, aritmetik ortalama, frekans ve yüzde dağılımı, normallik (Kolmogorov-Smirnov) ve farklılık (T- testi ve Anova) testleri yapılmıştır.

\section{4. Ölçeklerin Güvenirliliği ve Geçerliliği}

Anketlerde güvenilirlik ve geçerlilik önemli olduğundan, bu iki özelliğin sonuçları dikkate alınmıştır. Geçerlilik, bir testin veya ölçeğin ölçülme derecesidir (Altunışık vd. 2010). Bu açıklamadan da anlaşılacağı gibi geçerlilik derecesi ölçmek istediğimiz alternatif değişkenlerin ifade edilebilme derecesine bağlıdır. Güvenilirlik, ‘bir testin veya ölçeğin ölçmek istediği şeyi istikrarlı ve tutarlı bir şekilde ölçme derecesidir. Likert tipli anket çalışmalarında ölçeklerin iç tutarlılığının test edilmesi gerekmektedir. Likert tipli ölçeklerin güvenirliliğinin ölçülmesi için, Cronbach Alfa testi yapılmaktadır. Bu tür ölçeklerin güvenilirlik katsayısının 1'e yakın olması gerekmektedir. Katılımcılar anket uygulamalarını cevapladıktan sonra Demografik sorular dışında 12 soruya güvenirlilik testi yapılmıştır. Güvenirlilik analizinin sonuçları aşağıdaki Tablo 3'de gösterilmiştir.

Tablo 3. Cronbach's Alpha Güvenirlilik Analizi

\begin{tabular}{|c|c|c|}
\hline Ölçekler & Cronbach's Alpha & Soru Sayısı \\
\hline Gelir Yönetimi & 0,953 & 12 \\
\hline
\end{tabular}

Ankette Cronbach's Alpha testinin güvenilir sayıla bilmesi için alfa değerinin en az 0,7 olması gerekmektedir. Yukarıda görüldüğü gibi Cronbach's alpha katsayısı 0,953 olarak ortaya çıkmıştır. Bu değer kabul edilebilen sınırlar içerisinde bir değer olduğundan verilerin güvenilir olduğunu rahatlıkla söyleyebiliriz.

Anketteki ölçeklerin geçerlilik katsayısının ölçülmesi için açıklayıcı faktör analizleri yapılmıştır. Çalışmadakı verilerin faktör analizine uygunluğu Kasier-Meyer-Olkin (KMO) ve Barlett testi ile açıklanabilir (Büyüköztürk, 2010). Kullanılan örneklemin yeterliliğinin anlaşılmasına yardımcı olan KMO testinin sonucunun 0,60 üzerinde gerçekleşmesi beklenmekte; bu sonucun 0,80 üzerinde olması durumu ise mükemmel olarak değerlendirilmektedir. Diğer türlü faktör analizi için şartlar uygun olmayacaktır. KMO değerinin ise en az 0,40 olmasına dikkat edilmelidir (Kozak, 2015). 
S. Büyükipekci - İ. İslamzade 13/1 (2021) 176-191

Tablo 4. Gelir Yönetimi Uygulamalarının Değerlendirilmesi Ölçeklerinin Faktör Analizi

\begin{tabular}{|l|c|}
\hline \multicolumn{1}{|c|}{ Ölçekler } & Faktör Yükü \\
\hline Gelir yönetimi uygulamalarının genel giderlerin azalmasına yardımıı olması &, 758 \\
\hline Gelir yönetimi uygulamalarının maliyetleri azaltması &, 842 \\
\hline Gelir yönetimi uygulamalarının işletme faaliyetlerini kontrole yardımcı olması &, 797 \\
\hline Gelir yönetimi uygulamalarının müşteri ilişkileri yönetiminde etkinliği arttırması &, 673 \\
\hline Gelir yönetimi uygulamalarının kaynakların daha verimli şekilde kullanılmasını sağlaması &, 736 \\
\hline Gelir yönetimi uygulamalarının otelin karlılığını arttırması &, 840 \\
\hline Gelir yönetimi uygulamalarının otelin rekabet edilebilir avantajını arttırması &, 868 \\
\hline Gelir yönetimi uygulamalarının etkin rekabet stratejileri geliştirmesine yardımcı olması &, 851 \\
\hline Gelir yönetimi uygulamalarının oda satışlarını arttırması &, 784 \\
\hline Gelir yönetimi uygulamalarının doluluk oranını arttırması &, 806 \\
\hline Gelir yönetimi uygulamalarının müşteri kitlesini arttırması &, 807 \\
\hline Gelir yönetimi uygulamalarının hizmet kalitesini yükseltmesi &, 839 \\
\hline Açıklanan varyans (\%) & $\mathbf{7 4 , 9 2 7}$ \\
\hline Cronbach alfa katsayısı & $\mathbf{0 , 8 4 7}$ \\
\hline
\end{tabular}

KMO: 0,862, Barlett Testi: 561,642, p<0,001

Tablo 4' deki verile göre $\mathrm{KMO}=0,862>0,50$ olduğundan dolayı veri setinin faktör analizi için uygun olduğunu söyleyebiliriz. Bir diğer Test ise Bartlett testidir. Bartlett testinin sonucuna göre $p<0,001$ 'dir. Buna görede verilerin geçerliliğinin yüksek olası ve faktör analizinin yapılması için uygun olduğu belirlenmektedir.

\section{BULGULAR}

\subsection{Katılımcılar ile İlgili Demografik Bilgiler}

Araştırmaya toplam 50 kişi katılmıştır. Katılımcılara ait demografik değişkenler Tablo 5 'te verilmiştir.

Tablo 5. Katılımcılara Ait Demografik Değişkenler

\begin{tabular}{|c|c|c|c|}
\hline \multicolumn{2}{|r|}{ Değişken } & \multirow{2}{*}{$\begin{array}{c}\text { Frekans } \\
18\end{array}$} & \multirow{2}{*}{$\begin{array}{c}\text { Yüzde (\%) } \\
36,0\end{array}$} \\
\hline \multirow{3}{*}{ Cinsiyet } & Kadın & & \\
\hline & Erkek & 32 & 64,0 \\
\hline & Toplam & 50 & 100 \\
\hline \multirow{8}{*}{ Yaş } & $18-23$ yaş & 3 & 6,0 \\
\hline & $24-29$ yaş & 12 & 24,0 \\
\hline & $30-35$ yaş & 23 & 46,0 \\
\hline & 36-41yaş & 7 & 14,0 \\
\hline & $42-47$ yaş & 3 & 6,0 \\
\hline & $48-53$ yaş & 2 & 4,0 \\
\hline & 54 ve üzeri & - & - \\
\hline & Toplam & 50 & 100 \\
\hline \multirow{3}{*}{ Medeni Durum } & Evli & 31 & 62,0 \\
\hline & Bekar & 19 & 38,0 \\
\hline & Toplam & 50 & 100 \\
\hline \multirow{5}{*}{ Eğitim Durumu } & İlköğretim & 1 & 2,0 \\
\hline & Lise Mezunu & 4 & 8,0 \\
\hline & Üniversite Mezunu & 43 & 86,0 \\
\hline & Yüksek Lisans/ Doktora & 2 & 4,0 \\
\hline & Toplam & 50 & 100 \\
\hline & $0-1000$ & - & - \\
\hline & $1001-2000$ & - & - \\
\hline
\end{tabular}


S. Büyükipekci - İ. İslamzade 13/1 (2021) 176-191

\section{Aylık Gelir}

\begin{tabular}{|l|c|c|}
\hline $2001-3000$ & 23 & 46,0 \\
\hline $3001-4000$ & 20 & 40,0 \\
\hline 4000 ve üzeri & 7 & 14,0 \\
\hline Toplam & $\mathbf{5 0}$ & $\mathbf{1 0 0}$ \\
\hline
\end{tabular}

Anketi cevaplayan katılımcıların 18'i (\% 36) kadın, 32'si (\% 64) erkeklerden oluşmaktadır. Dağıtılmış anket sorularını cevaplayan otel yöneticilerinin yaş durumuna bakıldığında 3 (\% 6) kişi 18-23 yaş aralığında, 12'si (\% 24) 24-29 yaş aralığında, 23'ü (\% 46) 30-35 yaş aralığında, 7'si (\% 14) 36-41 yaş aralığında, 3'ü (\% 6) 42-47 yaş aralığına, 2'si (\% 4) 48-53 yaş aralığındadır. 54 ve üzeri yaşlarda ise katılımcı bulunmamaktadır. Katılımcıların medeni durumuna göre 31'i (\% 62) evli, 19'u (\% 38) bekârdır. Eğitim durumuna baktığımızda katılımcıların 43'ü (\% 86) Üniversite mezunudur. Lise mezunu katılımcıların sayısı 4 (\% 8), Yüksek Lisans ve Doktoralı katılımcıların sayısı 2'dir (\% 4). Eğitim durumuna baktığımızda katılımcılardan yalnız 1'i (\% 2) ilköğretim mezunu olduğu görünmektedir. Anket katılımcılarının aylık geliri 0-1000 ve 1001-2000 Aralıkları üzerindedir. 2001-3000 Aralığında geliri olan 23 (\% 46), 3001-4000 Aralığında geliri olan 20 (\% 40), 4000 ve üzeri aylık geliri olan 7 (\% 14) katılımcı vardır.

\subsection{Katılımcıların Otel İşletmeleri İle İlgili Genel Bilgiler}

Araştırmaya katılmış olan Otel İşletmelerinin yatak kapasiteleri, otel statüsü ve müşteri profili ile ilgili genel bilgiler Tablo 6'da verilmektedir.

Tablo 6. Otel İşletmeleri İle İlgili Genel Bilgiler

\begin{tabular}{|c|c|c|c|}
\hline & Değişken & Frekans & Yüzde (\%) \\
\hline \multirow{5}{*}{ Otelin Yatak Kapasitesi } & $0-200$ & - & - \\
\hline & \begin{tabular}{|l|}
$201-400$ \\
\end{tabular} & 50 & 100,0 \\
\hline & $401-600$ & - & - \\
\hline & \begin{tabular}{|l|}
$601-800$ \\
\end{tabular} & - & - \\
\hline & Toplam & 50 & 100,0 \\
\hline \multirow{4}{*}{ Otelinizin Statüsü } & Uluslararası zincire bağlı & 30 & 60,0 \\
\hline & \begin{tabular}{|l|} 
Ulusal zincire bağlı \\
\end{tabular} & 10 & 20,0 \\
\hline & Ulusal şahıs otel işletmesi & 10 & 20,0 \\
\hline & Toplam & 50 & 100,0 \\
\hline \multirow{6}{*}{ Müşteri Profil } & İş amaçlı & 1 & 2,0 \\
\hline & Tatil amaçlı & 1 & 2,0 \\
\hline & Kongre & - & - \\
\hline & Hepsi & 48 & 96,0 \\
\hline & Diğer & - & - \\
\hline & Toplam & 50 & 100,0 \\
\hline \multirow{4}{*}{ Otelin Çalışan Sayısı } & $1-70$ & 10 & 20,0 \\
\hline & 71-140 & 30 & 60,0 \\
\hline & 141 ve üzeri & 10 & 20,0 \\
\hline & Toplam & 50 & 100,0 \\
\hline \multirow{5}{*}{ Otelin Faaliyet Süresi } & $1-3$ y1l & 10 & 20,0 \\
\hline & $4-6$ y1l & 10 & 20,0 \\
\hline & \begin{tabular}{|l|}
$7-9$ y1l \\
\end{tabular} & 10 & 20,0 \\
\hline & 10 ve üzeri & 20 & 40,0 \\
\hline & Toplam & 50 & 100,0 \\
\hline
\end{tabular}

Tablo 6 incelendiğinde araştırmaya katılan otel işletmelerinin yatak kapasitelerinin aynı sayıda olduğu görülmektedir. Çalışma 1 den fazla otelde yapıldığı için yatak kapasitesi, otel statüsü, müşteri profili gibi 
S. Büyükipekci - İ. İslamzade 13/1 (2021) 176-191

sorular her otelde genellilkle farklı olduğu için katılımcılara sorulmuştur. Yukarıdaki tabloda da bu soruların frekans ve yüzdeleri gösterilmektedir. Ayrıca bu sorular farklılıklarında ölçülmesi için de kullanılmıştır.

Araştırmaya katılan üst düzey yöneticilerden 30’u (\% 60) otel statüsünü uluslararası zincire bağlı, 10’u (\% 20) ulusal zincire bağlı, 10'u (\% 20) ulusal şahıs otel işletmesi olarak cevaplanmıştır. Bütün katılımcılar görev yaptıkları otel işletmelerinde müşteri profillerinin hepsini kullandıklarını söylemektedirler. Katılımcılar çalıştığ cevaplamışlardır. Tablo 6'ya baktığımızda otelin faaliyet süresini yöneticilerin 10'u (\%20) 1-3 yıl, 10'u (\%20) 4-6 yıl, 10’u (\% 20) 7-9 yıl, 20'si (\%40) 10 ve üzeri olarak cevaplamışlar.

\section{3. İşletmelerin Gelir Yönetimi Kullanma Durumları İle İlgili Bulgular}

Araştırmaya katılan otel işletmelerinin gelir yönetimi Uygulamalarının kullanım süreleri ile ilgili tablo 7'de verilmektedir.

Tablo 7. Otellerde Gelir Yönetimini Kullanma Süresi

\begin{tabular}{|l|c|c|}
\hline \multicolumn{1}{|c|}{$\begin{array}{c}\text { Gelir Yönetimini Kaç Yıldır } \\
\text { Kullanıyorsunuz? }\end{array}$} & Frekans & Yüzde (\%) \\
\hline Kullanmiyoruz & 10 & 20,0 \\
\hline 1-4 yıl & 30 & 60,0 \\
\hline 5-8 yıl & 10 & 20,0 \\
\hline 9-12 yıl & - & - \\
\hline 13 ve üzeri & - & - \\
\hline Toplam & $\mathbf{5 0}$ & $\mathbf{1 0 0 , 0}$ \\
\hline
\end{tabular}

Yukardaki Tablo'yu incellediğimizde katılımcıların 10’u (\% 20) görev yaptıkları otellerde gelir yönetimini kullanmadıkları görülmüştür. Ayrıca katılımcıların 30'u (\% 60) 1-4 yıl, 10'u (\% 20) 5-8 yıl gelir yönetinmini kullandıklarını belirtmiştir. Araştırmanın yapıldığ 5 yıldızlı otellerin gelir yönetimi kullanım sürelerine bakıldığında genel olarak son yıllarda kullandığı söylenebilir.

Tablo 8. Otel İşletmelerinin Gelir Müdürü Olma Durumları

\begin{tabular}{|l|c|c|}
\hline \multicolumn{1}{|c|}{$\begin{array}{c}\text { Otelinizde Gelir Yönetimi Müdürü } \\
\text { Bulunuyor mu? }\end{array}$} & Frekans & Yüzde (\%) \\
\hline Evet & 40 & 80,0 \\
\hline Hayır & 10 & 20,0 \\
\hline Toplam & $\mathbf{5 0}$ & $\mathbf{1 0 0 , 0}$ \\
\hline
\end{tabular}

Araştırmanın yapıldığı otellerde anketi cevaplayan üst düzey yöneticilerin 40’1 (\% 80) görev aldıkları işletmelerde gelir yönetimi müdürünün bulunduğunu, 10’u $(\% 20)$ gelir yönetimi müdürünün bulunmadığını söylemektedirler.

Tablo 9. Otel İşletmelerinde Gelir Müdürünün Hangi Departmana Bağlı Olması Durumu

\begin{tabular}{|l|c|c|}
\hline \multicolumn{1}{|c|}{$\begin{array}{c}\text { Gelir müdürünün organizasyon içinde } \\
\text { bağlı olduğu departman? }\end{array}$} & Frekans & Yüzde (\%) \\
\hline Satış ve pazarlama bölümü & 40 & 80,0 \\
\hline Ön büro departmanı & - & - \\
\hline Bağımsız & 10 & 20,0 \\
\hline Diğer & - & - \\
\hline Toplam & $\mathbf{5 0}$ & $\mathbf{1 0 0}$ \\
\hline
\end{tabular}

Tablo 9'u incelendiğimizde katılımcılar gelir müdürünün organizasyon içinde en çok satış ve pazarlama bölümüne bağlı olarak çalıştığını cevaplamışlardır. 
S. Büyükipekci - İ. İslamzade 13/1 (2021) 176-191

Tablo 10. Gelir Müdürü Bulunmayan Otel İşletmelerinde Gelir Yönetimi İle İlgili Sorumlulukları Yerine Getiren Yönetici

\begin{tabular}{|l|c|c|}
\hline $\begin{array}{c}\text { Gelir Müdürü Yoksa Onun } \\
\text { Sorumluluklarını Yerine Getiren Yönetici? }\end{array}$ & Frekans & Yüzde (\%) \\
\hline Otel müdürü & 10 & 20,0 \\
\hline Ön büro müdürü & - & - \\
\hline Satış ve pazarlama müdürü & 30 & 60,0 \\
\hline Rezervasyon Müdürü & - & - \\
\hline Finans direktörü & 10 & 20,0 \\
\hline Toplam & $\mathbf{5 0}$ & $\mathbf{1 0 0 , 0}$ \\
\hline
\end{tabular}

Tablo 10’a bakıldığında çalışmanın yapıldığı otellerde yer alan üst düzey yöneticiler(katılımcılar), işletmede gelir müdürü bulunmaması durumunda onun sorumluluklarını en çok yerine getiren yöneticinin satış ve pazarlama müdürü olarak cevaplamaktadırlar.

Tablo 11. Otel İşletmelerinde Gelir Yönetimi Uygulamalarını İzlemek İçin Gelir Yönetimi Komitesine Sahip Olma Durumları

\begin{tabular}{|l|c|c|}
\hline \multicolumn{1}{|c|}{$\begin{array}{c}\text { Otelinizde Gelir Yönetimi Komitesinin } \\
\text { Olup Olmadığı }\end{array}$} & Frekans & Yüzde (\%) \\
\hline Evet & 20 & 40,0 \\
\hline Hayır & 30 & 60,0 \\
\hline Toplam & $\mathbf{5 0}$ & $\mathbf{1 0 0 , 0}$ \\
\hline
\end{tabular}

Yukarıdaki Tablo incelendiğinde uygulamanın yapıldığı otellerde araştırmaya katılan yöneticilerin 20'si (\%40) gelir yönetimi komitesinin bulunduğunu 30’u (\%60) gelir yönetimi komitesinin bulunmadığı söylemektedirler

Tablo 12. Otel İşletmelerinde Gelir Yönetimi Komitesi Varsa Bölüm Yöneticileri

\begin{tabular}{|l|c|c|}
\hline \multicolumn{1}{|c|}{$\begin{array}{c}\text { Gelir Yönetimi Komitesi Kurulduğunda } \\
\text { Bölüm Yöneticileri }\end{array}$} & Frekans & Yüzde (\%) \\
\hline Otel Müdürü & 44 & 88,0 \\
\hline Satış Ve Pazarlama Müdürü & 5 & 10,0 \\
\hline Ön Büro Müdürü & - & - \\
\hline Gelir Müdürü & 1 & 2,0 \\
\hline Rezervasyon Müdürü & - & - \\
\hline Yiyecek İçecek Müdürü & - & - \\
\hline Toplam & $\mathbf{5 0}$ & $\mathbf{1 0 0 , 0}$ \\
\hline
\end{tabular}

Tablo 12 incelendiğinde gelir yönetimi komitesi kurulduğu zaman bölüm yöneticilerinden biri olarak en çok otel müdürünün $44(\%$ 88) katılımcılar tarafından cevaplandığını görebiliriz. Ayrıca satış ve pazarlama müdürünü seçen $5(\% 10)$, gelir müdürünü seçen $1(\% 2)$ katılımcı görünmektedir. 


\section{4. İşletmelerin Gelir Yönetimi Uygulamaları Değerlendirilmesi İle İlgili Bulguları}

Tablo 13. Otel İşletmelerinde Gelir Yönetimi Uygulamalarının Değerlendirilmesi İle İlgili Bulgular

\begin{tabular}{|c|c|c|c|c|c|c|c|c|c|c|c|c|}
\hline $\begin{array}{l}\text { हे } \\
\text { io } \\
\text { ż } \\
\text { है }\end{array}$ & $\begin{array}{l}\text { Otel İssletmelerinde Gelir } \\
\text { Yönetiminin Uygulamalarının } \\
\text { Değerlendirilmesi İle İlgili } \\
\text { Algılar }\end{array}$ & & 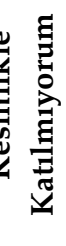 & & 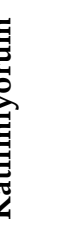 & & 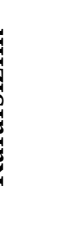 & & & & 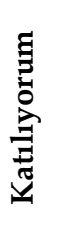 & ORT \\
\hline \multirow[b]{2}{*}{1} & & $\mathbf{N}$ & $\%$ & $\mathbf{N}$ & $\%$ & $\mathbf{N}$ & $\%$ & $\mathbf{N}$ & $\%$ & $\mathbf{N}$ & $\%$ & \\
\hline & $\begin{array}{l}\text { Gelir yönetimi uygulamalarının } \\
\text { genel giderlerin azalmasına } \\
\text { yardımcı olması }\end{array}$ & 3 & 6,0 & 2 & 4,0 & 9 & 18,0 & 26 & 52,0 & 10 & 20,0 & 3,76 \\
\hline 2 & $\begin{array}{l}\text { Gelir yönetimi uygulamalarının } \\
\text { maliyetleri azaltması }\end{array}$ & 2 & 4,0 & 4 & 8,0 & 7 & 14,0 & 24 & 48,0 & 13 & 26,0 & 3,84 \\
\hline 3 & $\begin{array}{l}\text { Gelir yönetimi uygulamalarının } \\
\text { işletme faaliyetlerini kontrole } \\
\text { yardımcı olması }\end{array}$ & 2 & 4,0 & 2 & 4,0 & 8 & 16,0 & 24 & 48,0 & 14 & 28,0 & 3,92 \\
\hline 4 & $\begin{array}{l}\text { Gelir yönetimi uygulamalarının } \\
\text { müşteri ilişkileri yönetiminde } \\
\text { etkinliği arttırması }\end{array}$ & 4 & 8,0 & 5 & 10,0 & 8 & 16,0 & 19 & 38,0 & 14 & 28,0 & 3,68 \\
\hline 5 & $\begin{array}{l}\text { Gelir yönetimi uygulamalarının } \\
\text { kaynakların daha verimli şekilde } \\
\text { kullanılmasını sağlaması }\end{array}$ & 2 & 4,0 & 6 & 12,0 & 3 & 6,0 & 26 & 52,0 & 13 & 26,0 & 3,84 \\
\hline 6 & $\begin{array}{l}\text { Gelir yönetimi uygulamalarının } \\
\text { otelin karlılığını arttırması }\end{array}$ & 3 & 6,0 & 1 & 2,0 & 8 & 16,0 & 19 & 38,0 & 19 & 38,0 & 4,00 \\
\hline 7 & $\begin{array}{l}\text { Gelir yönetimi uygulamalarının } \\
\text { otelin rekabet edilebilirliğini } \\
\text { arttırması }\end{array}$ & 4 & 8,0 & 3 & 6,0 & 4 & 8,0 & 27 & 54,0 & 12 & 24,0 & 3,80 \\
\hline 8 & $\begin{array}{l}\text { Gelir yönetimi uygulamalarının } \\
\text { etkin rekabet stratejileri } \\
\text { geliştirmesine yardımcı olması }\end{array}$ & 3 & 6,0 & 2 & 4,0 & 10 & 20,0 & 18 & 36,0 & 17 & 34,0 & 3,88 \\
\hline 9 & $\begin{array}{l}\text { Gelir yönetimi uygulamalarının } \\
\text { oda satışlarını arttırması }\end{array}$ & 3 & 6,0 & 2 & 4,0 & 9 & 18,0 & 18 & 36,0 & 18 & 36,0 & 3,92 \\
\hline 10 & $\begin{array}{l}\text { Gelir yönetimi uygulamalarının } \\
\text { doluluk oranını arttırması }\end{array}$ & 2 & 4,0 & 4 & 8,0 & 9 & 18,0 & 20 & 40,0 & 15 & 30,0 & 3,84 \\
\hline 11 & $\begin{array}{l}\text { Gelir yönetimi uygulamalarının } \\
\text { müşteri kitlesini arttırması }\end{array}$ & 2 & 4,0 & 1 & 2,0 & 12 & 24,0 & 26 & 52,0 & 9 & 18,0 & 3,78 \\
\hline 12 & $\begin{array}{l}\text { Gelir yönetimi uygulamalarının } \\
\text { hizmet kalitesini yükseltmesi }\end{array}$ & 4 & 8,0 & 0 & 0,00 & 9 & 18,0 & 23 & 46,0 & 14 & 28,0 & 3,86 \\
\hline
\end{tabular}

Tablo 13 ten anlaşıldığı üzere tüm pozisyonların ortalaması 3 ve daha yüksek olduğu için yöneticilerin bu faktörleri olumlu olarak değerlendirdikleri belirlenmiştir. Gelir yönetimi kullanan bir otel işletmesinin gelir yönetimi uygulamaları işletmenin faaliyetlerini kontrol etmeye yardımcı olabileceğine inanılmaktadır. Gelir yönetimi uygulaması otel şirketlerinin kaynaklarını daha verimli kullanmalarını sağlamıştır. Gelir yönetimi uygulaması otel işletmesinin karlılığını artırmış ve otel işletmesinin rekabet avantajlarını artırmıştır. Otellerde gelir yönetimi uygulamalarının kullanılması oda satışlarını artması ve doluluk oranının yükselmesine büyük etki sağladığı tespit edilmiştir. 


\subsection{Farklılık Analizleri İle İlgili Bulgular}

Konya'da faaliyet gösteren beş yıldızlı otel işletmelerinde, gelir müdürünü bulunup bulunmaması, otelde gelir yönetimi uygulamalarını izlemek için gelir yönetimi komitesinin kurulup kurulmaması, otellerin müşteri profili gibi seçilmiş çeşitli gruplarla gelir yönetimi uygulamalarının değerlendirilmesi arasında anlamlı farklılıkların olup olmadığı test edilmektedir. Farklılıkların ölçülmesi için ilk önce verilerin normallik testi yapılmıştır. Bu test ile ilgili bulgular Tablo 14'te verilmiştir.

Tablo 14. Verilerin normal dağılımı için Kolmogorov-Smirnov testi ile ilgili bulgular

\begin{tabular}{|c|c|c|c|c|c|}
\hline Değerler & $\mathbf{N}$ & Ort. & SS & $\begin{array}{c}\text { Kolmogorov- } \\
\text { Smirnov }\end{array}$ & $\mathbf{P}$ \\
\hline $\begin{array}{c}\text { Gelir yönetimi uygulamalarının } \\
\text { değerlendirilmesi }\end{array}$ & 50 & 4,091 & 0,871 & 0,157 & $\mathbf{0 , 0 6}$ \\
\hline
\end{tabular}

$\mathrm{p}>0,05^{*}$

Tablo 14'de, anketteki verilerin normal dağılımının analiz sonuçları gösterilmiştir. Analizde cevap sayısı 30 dan fazla olduğu için normallik testlerinden Kolmogorov-Smirnov testi yapılmıştır. Bu testin sonuçlarına göre veriler normal dağılmıştır ( $\mathrm{p}>0,05)$.

Çalışmada farklılık analizlerinin yapılması için parametrik dağılmış olan verilerde yapılan ikili guruplar arasında T-testi, ikiden fazla gruplar arasında Anova testinin yapılması uygun görülmüştür.

Tablo 15. İşletmelerde Gelir Müdürünün Bulunmasına Göre Otellerde Gelir Yönetimi Uygulamalarında Oluşa Bilecek Farklılıklara İlişkin T-Testi Bulguları

\begin{tabular}{|l|c|c|c|c|c|}
\hline \multicolumn{1}{|c|}{$\begin{array}{c}\text { Otel İşletmenizde Gelir Müdürü } \\
\text { Bulunuyor mu? }\end{array}$} & N & Ort. & SS & T & P \\
\hline Evet & 40 & 3,777 & 0,948 & & \\
\cline { 1 - 5 } Hayır & 10 & 4,109 & 0,562 & $-0,966$ & $\mathbf{0 , 3 4 1}$ \\
\hline
\end{tabular}

$\mathrm{p}<0,05$ *

İşletmelerde gelir müdürünün bulunup bulunmamasına göre otellerde gelir yönetimi uygulamalarının değerlendirilmesinde oluşabilecek farklılıkların belirlenmesine yönelik Tablo 15 'de verilen T-testinin sonuçlarına göre farklılığın olmadığı görülmektedir $(p>0,05)$. Ancak gelir müdürünün bulunma durumuna göre otellerde gelir yönetiminin uygulamalarının değerlendirilmesi karşılaştırıldığında, gelir müdürü bulunmayan otellerin ortalaması $(4,000)$ olduğu görülmektedir. Buna karşılık gelir yönetimi bulunan otellerin ortalaması $(3,791)$ şeklindedir.

Tablo 16. İşletmelerde Gelir Yönetimi Komitesinin Kurulmasına Göre Otellerde Gelir Yönetimi Uygulamalarının Değerlendirilmesinde Oluşa Bilecek Farklılıklara İlişkin T-Testi Bulguları

\begin{tabular}{|l|c|c|c|c|c|}
\hline $\begin{array}{c}\text { Otelde gelir yönetimi komitesi kuruldu } \\
\text { mu? }\end{array}$ & N & Ort. & SS & T & P \\
\cline { 1 - 4 } Evet & 20 & 3,750 & 0,988 & & \\
\cline { 1 - 6 } Hayır & 30 & 3,905 & 0,768 & 0,033 & $\mathbf{0 , 9 7 4}$ \\
\hline
\end{tabular}

$\mathrm{p}<0,05$ *

Katılımcıların çalıştıkları otellerde gelir yönetimi komitesinin kurulmasının anlamlı bir şekilde farklılaşıp farklılaşmadığını test etmek amacıyla bağımsız gruplar için T-testi kullanılmıştır. Analiz sonucunda otellerde gelir yönetimi komitesinin kurulmasında anlamlı bir farklılık bulunmamıştır $(p>0,05)$. İşletmelerde gelir yönetimi komitesinin bulunma oranı $(3,847)$, gelir yönetimi komitesi bulunmama oranında $(3,839)$ yüksektir. 
Tablo 17. Müşteri Profiline Göre Otellerde Gelir Yönetimi Uygulamalarının Değerlendirilmesinde Oluşa Bilecek Farklılıklara İlişkin Anova Testi Bulguları

\begin{tabular}{|l|c|c|c|c|c|}
\hline \multicolumn{1}{|c|}{ Müşteri Profili } & $\mathbf{N}$ & Ort. & SS & F & P \\
\hline İş Amaçlı & 1 & 2,670 & 0 & & \\
\cline { 1 - 4 } Tatil Amaçlı & 1 & 3,000 & 0 & \multirow{2}{*}{1,457} & \multirow{2}{*}{$\mathbf{0 , 2 4 3}$} \\
\cline { 1 - 4 } Kongre & 0 & 0 & 0 & & \\
\hline Hepsi & 48 & 3,885 & 0,863 & & \\
\hline Diğer & 0 & 0 & 0 & & \\
\hline
\end{tabular}

$\mathrm{p}<0,05$ *

İşletmelerin müşteri profiline göre genel gelir yönetimi uygulamalarının değerlendirilmesi karşılaştırıldığında anlamlı bir farklılığın olup olmadığını öğrenmek için yapılan Anova testinin sonuçları Tablo 17'de gösterilmektedir. Bu testin sonucuna göre işletmelerin müşteri profilinin genel gelir yönetimi maddeleri ile anlamlı bir farklılığının olmadığı $(\mathrm{p}>0,05)$ görülmektedir. Ayrıca bu gruplar karşılaştırıldığında en yüksek ortalamanın hepsi $(3,885)$ grubuna ait olduğunu söyleyebiliriz.

\section{SONUÇ ve TARIŞMA}

Otel işletmelerinin amacı maliyetleri minimize ederek kar maksimizasyonunu sağlamaktır. Bu bağlamda fiili kapasiteyi normal kapasiteye yaklaştırarak, atıl kapasiteyi minimize etmeye çalışmaktadır. Bu uygulama birim başına sabit maliyetlerin azalmasını sağlamaktadır. Sürekli gelişen gelir yönetimi sistemi, otel işletmeleri için yeni uygulamalar ortaya çıkarmaktadır. Gelir yönetiminin uygulanması otellerde sadece odaları satmakla değil, aynı zamanda odaların doluluğunu da artırır.

Otel işletmelerinde gelir yönetimi uygulamaları ülkemizde son yıllarda kullanılmaya başlanılmıştır. Buna rağmen araştırmanın yapılmış olduğu Konya'daki 5 yıldızlı otel işletmelerinin bu konuya yanıtları oldukça olumludur. Yapılmış olan anket uygulamasını cevaplayan 50 katılımcının (otel yöneticilerinin) 10'u işletmelerinde gelir yönetimi uygulamalarını kullanmadıklarını söylemektedirler. Konya ilinde yapılan anket çalışmasında 5 yıldızlı otel işletmelerinde görev alan üst düzey yöneticilerin verdikleri cevaplardan elde edilen sonuçlara bakıldığında, katılımcıların \% 40'ının görev aldığı otel işletmesinin 10 yıldan fazla faaliyet göstermesine rağmen katılımcıların \%6'sı 10 yıldır gelir yönetimi uygulamalarını kullandıklarını cevaplamaktadırlar. Bu araştırma ve bundan önce gelir yönetimi konusunda ülkemizde yapılan diğer akademik çalışmalara baktığımızda gelir yönetimi uygulamalarının 1970 li yıllarda yaranmasına rağmen Türkiye'de bu sistem işletmeler tarafından özellikle de otel işletmeleri tarafından henüz yeni gelişmekte ve kullanılmaktadır. Buna örnek olarak yapılan çalışmada da otel işletmeleri gelir yönetimi uygulamalarını çoğunlukla son 1-4 yıl içerisinde kullandıkları görülmektedir. Araştırma kapsamında çalışmanın yapıldığ 5 yıldızlı otel işletmelerinin $\% 80^{\prime}$ in de gelir yönetimi müdürünün bulunması ve gelir yönetimi uygulamaları ülkemizde yeni olmasına rağmen otel işletmeleri gelir yönetimine önem vermektedir.

Katılımcıların \% 60'ı araştırmadaki otellerin statülerini uluslararası zincire bağlı olan otel işletmesi olarak cevaplamışlar. Konya ilinde faaliyet gösteren 5 yıldızlı otel işletmelerinde görev alan üst düzey yöneticilere yapılan anket sorgulaması sonucunda araştırmanın yapıldığı otellerin bütün müşteri profillerini kullandıkları ortaya çıkmaktadır. Araştırma sonrasında otel içerisinde gelir yönetimi uygulamalarının en çok satış ve pazarlama bölümüne bağlı olarak faaliyet gösterdiği ortaya çıkmıştır. Aynı zamanda işletmelerde gelir yönetimi müdürü bulunmadığında gelir yönetimi uygulamalarını da satış ve pazarlama bölümü tarafından gerçekleştirilmektedir.

Konya' da faaliyet gösteren 5 yıldızlı otel işletmelerinde gelir yönetimi komitesi olmayan oteller, gelir yönetimi komitesi oluşturdukları zaman gelir yönetim uygulamalarının daha iyi bir şekilde kullanmalarına, satışlarının yükselmesine ve tam kapasite ile çalışmasına imkan sağlayacaktır. Gelir yönetiminden yüksek şekilde yararlanmak isteyen işletmeler diğer departmanlardan ayrı bir şekilde gelir yönetimi departmanı oluşturmalı, sürekli teknolojik gelişimleri takip etmeli ve çoğunlukla teknolojik yatırımlara önem vermeleri gerekmektedir. Uygulamanın yağıldığı otellerde görev alan üst düzey yöneticilerin $\% 60$ ' 1 işletmelerde gelir yönetimi komitesi bulunmadığını söylemektedirler.

Çalışmamızda gruplarla gelir yönetimi uygulamalarının değerlendirilmesi arasında farklılık testleri yapılmıştır. Araştırmada verilerin normal dağılıp dağılmadığını anlamak için normallik analizlerinden 
S. Büyükipekci - İ. İslamzade 13/1 (2021) 176-191

Kolmogorov-Smirnov testi yapılmıştır. Bu test sonrasında parametrik veriler için farklılık testleri yapılmıştır. İkili guruplar arasında T-testi ikiden fazla gruplar arasında ise Anova testi yapılmıştır. Fakat testler sonucunda ikili ve ikiden fazla gruplarla gelir yönetiminin uygulamalarının değerlendirilmesi arasında anlamlı bir farklılığın olmadığını sonucuna varılmıştır.

Bu konudaki literatür gözden geçirilirken, demografik özellikler ve işletmelerin faaliyet süreleri gibi faktörler, gelir yönetimi uygulamasında ilgili olabilecek faktörler olarak kabul edilmektedir. Bu araştırmada ise gelir yönetimi uygulamaları üzerinde farklı sonuçlar yaratabilecek etkenler olarak; müşteri profili, gelir müdürünün bulunması ve gelir yönetimi komitesinin bulunma zorunluluğu gibi faktörler söz konusu istatistik analizlere tabi tutulmuştur Analiz sırasında önemli farklılıklar bulunmamasına rağmen, bu çalışma hem alana sağladığı farklı bakış açısı yönünden hem de özgün literatür açısından ileride yapılacak araştırmalar için referans özelliği taşımaktadır.

Gelir yönetimi uygulamalarının turizm dalında oteller dışında diğer turizm işletmelerinde de yapılması önerilmektedir. Konaklama işletmelerinde, seyahat acentalarında gelir yönetimi uygulamalarının kullanılması, işletmelerin yüksek kar elde etmesine, doluluk oranının sürekli yüksek tutulmasına ve destinasyon bakımında bölgenin tercih edilmesine ve sosyal refahın yükselmesine büyük katkı sağlaması öngörülmektedir. Bu anlamda çalışmamızın ülkemiz açısından turizmin, otelcilik sektörünün gelişimine, turizm işletmelerinde sadece periodik olarak değil yıl genelinde doluluk oranını yüksek tutulmasında katkı sağlayacağı düşünülmüktedir. Ayrıca araştırma bundan sonra yapılacak olan gelir yönetimi uygulamaları ile ilgili çalışmalara referans olacak niteliğe sahiptir.

\section{KAYNAKÇA}

Altunışık , R., Coşkun, R., Bayraktaroğlu, S., \& Yıldırım, E. (2010). Sosyal Bilimlerde Araştırma Yöntemleri SPSS Uygulamalı. Sakarya: Sakarya Yayıncilık.

Annaraud, K. (2008). Implication of Statistical Indices in Hotel Room Revenue Analysis,. The Journal of Hospitality Financial Management, 16 (2),, 55-65.

Belobaba, P. (1987). “Air Travel Demand and Airline Seat Inventory Management”,. Doktora Tezi, Massachusetts Institute of Technology,.

Bertsimas , D., \& Shioda , R. (2003). “Restaurant Revenue Management”,. Operations Research, 51 (3),, 472-486.

Bujisic, M. (2014). “The Application of Revenue Management in Beverage Operations",. Journal of Foodservice Business Research, 17 (4),, 336-352.

Büyüköztürk, Ş. (2010). Sosyal Bilimler için Veri Analizi El Kitabı. Ankara: Pegem Akademi Yayıncılık.

Capiez, A., \& Kaya, A. (2004). Yield Management and Performance in the Hotel Industry,. Journal of Travel ETourism Marketing, 16 (4),, 21-31.

Cho, \& Choi. (2000). “Towards a Knowledge Discovery Framework for Yield Management in the Hong Kong Hotel Industry", International Journal of Hospitality Management, 19 (1),, 17-31.

Donaghy, M.-B. v. (1997). Implementing Yield Management: Lessons from the Hotel Sector,. International Journal of Contemporary Hospitality Management, 9 (2),, 50-54.

Fox, D. J. (1969). The Research Process in Education. New York: Holt, Rinehart, and Winston.

Guadıx, J. (2011). “An Overview of Revenue Management in Service Industries: An Application to Car Parks",. The Service Industries Journal, 31 (1),, 90-105.

Gür, Ç. (2014). Gelir Yönetimi Uygulmaları: Ankara'daki Otel İşletmelerinde Bir Araştırma. Düzce Üniversitesi Sosyal Bilimler Enstitüsü Dergisi.

Jerenz. (2008). Revenue Management and Survival Analysis in the Automobile Industry. Germany,: GablerVerlag.

Kimes, E. S. (2003). "Revenue Management: A Retrospective”,. Cornell Hotel and Restaurant Administration Quarterly, 44 (5),, 131-138. 
S. Büyükipekci - İ. İslamzade 13/1 (2021) 176-191

Kimes, S. E. (1989). “The Basic of Yield Management",. Cornell Hotel and Restaurant Administration Quarterly, $30(3), 14-19$,

Kimes, S. E. (2004). Restaurant Revenue Management. Cornell University School of Hotel Administration.

Korkmaz, Z. S. (2014). Küçük Ve Orta Ölçekli Konaklama İşletmelerinin Odalar Bölümünde Gelir Yönetimi. Ulusal Tez Merkezi.

Kozak, M. (2015). Bilimsel Araştırma:Tasarım, Yazım ve Yayım Teknikleri. Ankara: Detay Yayıncılık.

Kurgun, H. (2008). Konaklama İşletmelerinde Odalar Bölümü Yönetimi "Modern Yönetim Yaklaşımları ve Gelir Yönetimi",. Ankara: Detay Yayıncllık, 92.

Lai, K. K. (2005). "A Stochastic Approach to Hotel Revenue Optimization”,. Computers \& Operations Research, $32(5),, 1059-1072$

Mattila, S. C. (2004). Otel gelir yönetimi ve müşterilerin adalet algıları üzerindeki etkisi. Journal of Revenue and Pricing Management, 311-313.

Ören, V. E. (2005). Otel İşletmelerinde Getiri Yönetimi Ve Antalya Bölgesindeki Beş Yıldızlı Otel İşletmelerinde Bir Araştırma,. Turizm İşletmeciliği Ve Otelcilik Anabilim Dalı, Basılmamış Yüksek Lisans Tezi,Antalya, 23.

Öz, M. D. (2015). Kruvaziyer Turizmine Yönelik Tur Uygulamalarında Değer Zinciri Analizi,. (Yayınlanmamış Yüksek Lisans Tezi), Adnan Menderes Üniversitesi, Aydın., 86.

Padhi, S. S. (2011). “Competitive Revenue Management for Fixing Quota and Price of Hotel Commodities Under Uncertainty",. International Journal of Hospitality Management, 30 (3),, 725-734.

Relihan, J. W. (1989). "The Yield Management Approach to Hotel-Room Pricing",. Cornell Hotel and Restaurant Quarterly, 30 (1),, 40-45.

Salant, P., \& Dillman, D. (1994). How to Conduct Your Own Survey. Newyork: John Wiley \& Sons, Inc.

Sanchez, J. F. (2005). "Hotel Yield Management Using Different Reservation Modes",. SANCHEZ, Jean François ve Ahmet Satır (2005). "Hotel Yield Management Using DifferentInternational Journal of Contemporary Hospitality Management, 17 (2),, 136-146.

Sığırcı. (2015). Farklılaştırılmış Fiyatlandırma, Müşteri Grubu ve Para İadesinin Tüketicilerin Adalet Algısı, Tutum ve Davranışsal Niyetleri Üzerine Etkileri,. (Yayımlanmamış Doktora Tezi), Marmara Üniversitesi, İstanbul,.

Thompson, S. K. (2004). Restaurant Revenue Management at Chevys: Determining the Best Table Mix. Decision Sciences, 387-389.

Unurlu, Ç. (2010). Otel İşletmelerinin Odalar Bölümünde Gelir Yönetimi:İSTANBUL’DAKİ BEŞ YILDIZLI OTELLERDE BİR UYGULAMA. Yayınlanmamış Yüksek Lisans Tezi,Trakya Üniversitesi Sosyal Bilimler Enstitüsü, Edirne.

Yener, Ö., \& Gül, A. (2007). "Sosyal ve Eğitim Bilimleri Araştırmalarında Evren-Örneklem Sorunu”. Atatürk Üniversitesi Kazım Karabekir Eğitim Fakültesi Dergisi, Sayı 15, 394-422.

Yu, G. (1998). Operations Research in the Airline Industry, New York,. Springer Science Business Media,

Zheng Gu, J. M. (1998). Quadratic Models for Yield Management in Hotel Rooms Operation,. Progress in Tourism and Hospitality Research, 4, 245-253. 